\title{
The politeness prosody of the Javanese directive speech
}

\author{
F.X. RAHYONO
}

\begin{abstract}
This experimental phonetic research deals with the prosodies of directive speech in Javanese. The research procedures were: (1) speech production, (2) acoustic analysis, and (3) perception test. The data investigated are three directive utterances, in the form of statements, commands, and questions. The data were obtained by recording dialogues that present polite as well as impolite speech. Three acoustic experiments were conducted for statements, commands, and questions in directive speech: (1) modifications of duration, (2) modifications of contour, and (3) modifications of fundamental frequency. The result of the subsequent perception tests to 90 stimuli with 24 subjects were analysed statistically with ANOVA (Analysis of Variant). Based on this statistic analysis, the prosodic characteristics of polite and impolite speech were identified.

KEY WORDS

Speech politeness, prosody, acoustic analysis, intonation perception, directive speech, pitch movements, and Javanese.
\end{abstract}

\section{BACKGROUND}

This research aims to explore the prosodic characteristics of utterances in Javanese, perceived by the hearer as polite or impolite. ${ }^{1}$ Searl (1991) defines a directive utterance as an utterance used to make the hearer do something as communicated or suggested in the utterance. ${ }^{2}$

Politeness in verbal communication is an interesting research topic regarding language usage. In verbal interactions, a speaker hopes that what

I thank to Professor Hein Steinhauer (Leiden University) for reviewing this paper and for his suggesting to improve it.

$2 \quad$ See Gunarwan (2007: 185).

F.X. RAHYONO is a senior lecturer in the Faculty of Humanities, Javanese Program, University of Indonesia. He took his Ph.D. program in Linguistics at the University of Indonesia, 2003 with a thesis entitled Intonasi ragam bahasa Jawa Keraton Yogyakarta; Kontras deklarativitas, interogativitas, dan imperativitas. Before he wrote his thesis, he took a course in phonetics at the Leiden University Centre for Linguistics, the Netherlands. E-mail: frahyono.hum@ui.ac.id.

(C) 2009 Fakultas Ilmu Pengetahuan Budaya, Universitas Indonesia 
is communicated to the hearer invites a reply. In addition to that, the hearer hopes that he/she easily understands the information sent out by the speaker. Politeness is one of the speech strategies used by a speaker in order to get a reply by the hearer in accordance with the speaker's intention. Polite speech is speech that makes the hearer feel appreciated and free to do something. Therefore, a polite directive utterance is an utterance which does not make the hearer feel unappreciated, and which does not cause him/her to feel forced to do something that the speaker wants him/her to do.

Javanese is one of the local languages in Indonesia, which have registers for different situations, in accordance with the status relations between the speech participants. Structurally, the registers are formed by lexical and morphological variants. Each register has its own words, which are synonymous with other words in the other registers. Roughly, there are three registers in Javanese, which are used to state different relations between the speech participants, namely ngoko, madya, and krama. In addition to the fact that the krama register is used in formal situations, it is used to express deference to the hearer. ${ }^{3}$

Speakers who want to convey politeness usually choose honorific words. In practice, speech that is segmentally polite can be perceived as impolite if the prosodic (suprasegmental) features make the hearer feel unappreciated. ${ }^{4}$ Conversely, speech which segmentally does not contain honorific words could be used to convey a politeness when the prosody makes the hearer feel appreciated. Principally, politeness in speech is determined by the perception of the hearer.

To determine the role of prosody to the perception of politeness, this research has to start with an acoustic phonetic analysis. Through experimental phonetics, the prosodic characteristics perceived by the hearer as polite can be discovered. Van Heuven and Van Zanten (2007: 2-3) state that there are four phonetic components of prosody, namely (i) variation in pitch, (ii) variation in loudness, (iii) variation in quality (timbre), and (iv) timing variation. Prosodic research dealing with all four phonetic components would be too broad and too time-consuming, however. In accordance with the more modest aims of this paper, the phonetic components to be discussed are limited to two components, variation in pitch and timing variation.

In my opinion, politeness research dealing with the other two phonetic components (variation in loudness and variation in quality (timbre)) would involve investigating the emotional aspect of speech. Because the data in this research are emotionally neutral, delimitation of the phonetic component can be justified.

A further delimitation in this research is that politeness is investigated in directive speech only, because this is the types of speech act in which

3 Poedjosoedarmo (1979) classifies the Javanese registers in terms of speech levels. Errington $(1985,1988)$ names those registers (ngoko, madya, krama) speech styles (Rahyono 2002: 14, 2003: 62-63).

4 Gunarwan (2007: 260). 
politeness is most relevant. ${ }^{5}$ The decision to consider only directive speech was taken with regard to the theory of politeness presented by Brown and Levinson (1987).

\section{THEORY}

\subsection{POLITENESS THEORY}

Conversation is an activity of information transfer. Participants in a conversation communicate their messages to each other by means of language. In the communication act, the speaker and listener cooperate in order to achieve maximal correspondence between speaker's intention and hearer's interpretation of the utterances used in the conversation. A syntactically well formed utterance could be interpreted wrongly by the hearer, when the prosody of the related utterance is unclear.

In his paper "Logic and conversation" Grice (1991: 307) formulates a rough general Cooperative Principle as follows: "Make your conversational contribution such as is required, at the stage at which it occurs, by the accepted purpose or direction of the talk exchange in which you are engaged". This Cooperative Principle suggests how a message is successfully communicated. In order to make communication effective, the speech participants should cooperate. ${ }^{6}$ Grice's Cooperative Principle consists of four conversational maxims:

1. quantity: make your contribution as informative as is required; do not make your contribution more informative than is required;

2. quality: try to make your contribution one that is true;

3. relation: be relevant;

4. manner: be perspicuous.

In fact, in conversation a speaker intends to communicate more than what is said. ${ }^{7}$ It means that not everything the speaker wants to communicate is encoded in the language he/she uses. What the speaker intends to communicate must be derived by the hearer from the meaning of the words and from additional knowledge and information.

Speakers communicate what they mean indirectly. ${ }^{8}$ Leech (1983: 80) states that the Cooperative Principle cannot explain why people are often so indirect in conveying what they mean. Concerning the cooperative principle, Leech is more interested in a broader, socially and psychologically oriented application of pragmatic principles. A Politeness Principle is therefore a

\footnotetext{
Austin (1984: 149-164) classifies speech according to its illocutionary force.

See Gunarwan (2007: 162-163).

See Yule (1996: 35).

Searle (1991: 266) states that: "In indirect speech acts the speaker communicates to the hearer more than he actually says by way of relying on their mutually shared background information, both linguistic and nonlinguistic, together with the general powers of rationality and inference on the part of the hearer".
} 
necessary complement to the Cooperative Principle. Leech introduces such a politeness principle consisting of six maxims, namely as follows:

1. Tact maxim

a. Minimize cost to other

b. Maximize benefit to other

2. Generosity maxim

a. Minimize benefit to self

b. Maximize cost to self

3. Approbation maxim

a. Minimize dispraise of other

b. Maximize praise of other

4. Modesty maxim

a. Minimize praise of self

b. Maximize dispraise of self

5. Agreement maxim

a. Minimize disagreement between self and other

b. Maximize agreement between self and other

6. Sympathy maxim

a. Minimize antipathy between self and other

b. Maximize sympathy between self and other

Brown and Levinson (1987) put forward an influential theory of politeness, based on the concept of "face".${ }^{9}$ Brown and Levinson (1987: 60-61) state that some acts intrinsically threaten face. Face is something that is emotionally invested, and that can be lost, maintained, or enhanced, and must be constantly attended to in interaction. There are two related aspects of face, namely negative face and positive face. Negative face is the public self-image, which needs freedom of action and freedom from imposition. Positive face is the desire that the self-image be appreciated and approved. An utterance can make the listener lose face. Politeness is used by the speaker in order to save the face of the listener. Face, a public self-image, is a basic want, which members of a society in everyday interaction want to be respected. The politeness theory put forward by Brown and Levinson shows that politeness is measured in dealing with the threatening of face of the listener.

\subsection{DIRECTIVE SPEECH}

According to their function there are five types of speech acts: declarations, representatives, expressives, directives, and commissives (Yule 1996). This research deals with directives. A speaker expresses what he/she wants by means of directive speech. Directive speech includes the commands, orders, requests, and suggestions of a speaker.

Discussing indirect speech acts, Searle (1991: 268-269) states that: "In

$9 \quad$ See Thomas (1996: 168). 
directives, politeness is the chief motivation for indirectness". He distinguishes several categories of sentences that can be used to make indirect requests and other directives, among others:

- Group 1 Sentences concerning H's ability to perform A; ${ }^{10}$

- Group 2 Sentences concerning $S^{\prime}$ s wish or want that $\mathrm{H}$ will do to $\mathrm{A}$.

The target utterances used in this research are:

1. the indirect directives of group 1:

Mengko sore kudu dadi. This afternoon it should be ready

Sesuk bisa dadi apa ora? Could it be ready or not tomorrow?

2. the indirect directives of group 2:

Yen ora dadi ora sah digarap! If it cannot be ready, you shouldn't do it!

When the prosodic characteristics are changed these indirect directives conveying politeness can change into impolite direct directives or the other way around.

\subsection{SPEECH PROSODY}

A sentence does not convey any message when the words are only spoken without any other speech properties. Semantically, this sentence has a meaning. However, it does not have any speech force that makes a listener give a response. The message sent to the hearer by means of a spoken sentence as said before cannot be correctly perceived. Rahyono (2005: 48) states that an utterance formed by segmental speech constituents, namely words, cannot be used as an instrument of verbal communication, unless it is embedded by an illocutionary force. In spoken language, such illocutionary force is realized through the suprasegmental features or prosody of the utterance. An utterance "go now", for instance, is a statement, question, or command to the hearer when it is realized together with prosodic features conveying statement, question, or command. In his paper about prosody of speech, Nooteboom (1999) states that in normal speech pitch moves up and down in some nonrandom way, providing speech with recognizable melodic properties. In accordance with underlying patterns, segments or syllables are shortened or lengthened, some syllables or words are stressed to sound more prominent than others. Properties of speech that cannot be derived from the underlying sequence of phonemes are called suprasegmental properties of speech or prosodic features of speech. As said by Nooteboom, changes of pitch, timing, and prominence to the words or syllables, make up the speech force of the utterance intended and understood by the speech participants.

Nooteboom limited the treatment of prosody to speaker-controlled aspects of voice pitch, organized in perceived speech melody or intonation, and speaker-controlled aspects of speech timing, organized in the perceived or 'action'. 
rhythmical structure of speech. Based on these prosodic features, this research limits the scope of prosody to intonation and rhythm of speech. ${ }^{11}$

't Hart, Collier, and Cohen (1990: 10) state: "Intonation is the ensemble of pitch variations in the course of an utterance". Perceptually, pitch is a hearer's judgment on the melody of utterances. The hearers are able to perceive whether in a certain position in the utterance the pitch is higher or lower than those surrounding it, and whether the pitch moves up or down. ${ }^{12}$ The perceptual impression of the speech melody correlates with changes of the fundamental frequencies $\left(\mathrm{F}_{0}\right)^{13}$ of the segments in the course of the utterance. The changes of the frequencies relevant to the hearer's perception are just only those the speaker intentionally produces in order to convey the message he/ she wants to communicate. It means that the speaker changes the height of the pitch significantly in order to convey the illocutionary force intended. In accordance with the changes of the intonation the hearer perceives the message communicated by the speaker. By means of intonation the speaker is able to express the level of politeness without changing the words.

However, the human auditory capability to perceive changes of pitch is limited. Moreover, not all pitch variation is significant. Given this limited auditory capability, intonation contours can be manipulated to become linear lines without disturbing or changing the message. In the same way, pitch movement patterns can be visualized by linear lines, which may rise, fall, be flat or are a combination of these.
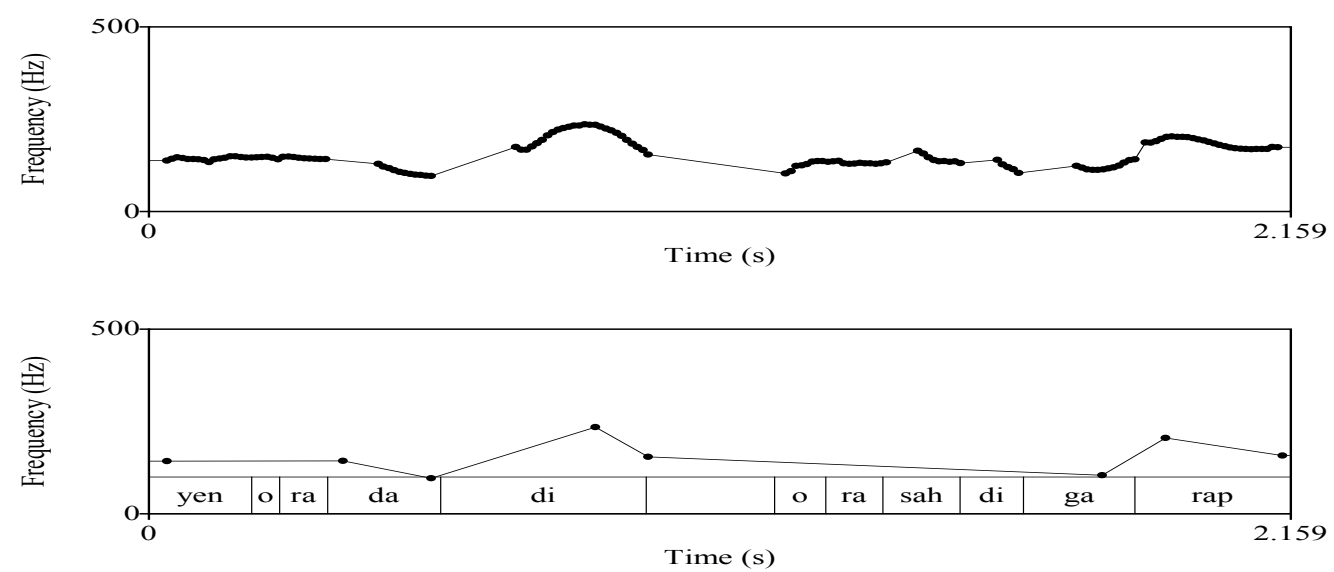

Figure 1. Close-copy stylization.

Yen ora dadi ora sah digarap.

11 Van Heuven (1994: 3) states that prosody is often divided into two broad categories of phenomena: (1) temporal structure and (2) melodic structure.

12 Acoustically, pitch perception is measured by semitones.

13 Cruttenden (1997: 4) states that fundamental frequencies $\left(\mathrm{F}_{0}\right)$ deal with acoustic measurement in Hertz $(\mathrm{Hz})$, whereas pitch is the perceptual term dealing with the hearer's judgment if the a sound of speech is high tone or low tone, moving up or down. 
To describe the intonation contours of an utterance, we need acoustic synthesis procedures called close-copy stylization. The synthesis of the intonation contours, namely close-copy stylization, must fulfill two prerequisites: (1) the synthesis must be perceptually similar to the original contour, (2) the close-copy of the melodic curves must be described with minimal linear lines visually representing the original melodic curves. ${ }^{14}$

The Figure 1 shows the actual frequency curve measured against time of the Javanese utterance yen ora dadi, ora sah digarap, followed by its close-copy stylization.

To summarize: intonation is pitch variation in the course of the utterance, formed by pitch movements as constituent units of intonation. The sequences of the pitch movements form a pitch contour. Pitch movement changes in the whole or in a part of the utterance also may change the perception of politeness involved.

\section{METHOD}

\subsection{PROCEDURE}

The object of this experimental phonetic research is the prosody of directive politeness in Javanese. This research uses qualitative as well as quantitative methods. Qualitative methods are applied in creating the instrument of data collecting, designing experiments, making perception tests, and analysing statistic data. Quantitative methods are used in analysing acoustic properties, quantifications of the subject's judgments in the perception test, as well as in the statistic significance tests. The research procedures used in this research are: (1) speech production, (2) acoustic analysis, (3) perception test, (4) statistic analysis, and (5) interpretation.

\subsection{DATA}

The data used in this research are directive utterances in the form of statements, commands, and questions. The data were produced by recording dialogues presenting polite as well as impolite utterances. Six kinds of dialogues were designed to represent the different politeness grades of the target sentences. The dialogues (literally translated) are as follows.

Dialogue (1)

A : Nyuwun sewu Mas Bei, nyuwun pirsa. Beskap pesenanku wingi wis dadi?

Excuse me, Mas Bei, I would like to ask you a question. Is the jacket I ordered yesterday ready?

B : Durung dadi.

Not yet.

A : Wadhuh, durung dadi, Mas? Sesuk arep tak enggo. Mengko sore kudu

14 See Rahyono (2003: 9-10). 
dadi! [Target sentence, polite]

To my surprise, it's not ready yet? I'm going to wear it tomorrow. This afternoon should be ready!

B : Iya, Dhik, aja kuwatir. Mengko awan wis dadi.

To be honest, yes, don't worry, my younger brother. This will be ready this afternoon.

Dialogue (2)

A : Nyuwun sewu Mas Bei, nyuwun pirsa. Beskap pesenanku wingi wis dadi? Excuse me, Mas Bei, I would like to ask you a question. Is the jacket I ordered yesterday ready?

B : Durung dadi.

Not yet.

A : Durung dadi? Nyuwun sewu Mas Bei, sesuk arep tak enggo. Mengko sore kudu dadi! [Target sentence, polite] Nyuwun sewu lho, Mas Bei. Aku perlu tenan, iki.

It's not ready yet? Excuse me, Mas Bei, I'm going to wear it tomorrow. This afternoon should be ready. Well, I'd like to ask for the apology, Mas Bei. I badly need it.

B : Iya Dhik, aja kuwatir. Mengko awan wis dadi.

To be honest, yes, don't worry, my younger brother. This will be ready this afternoon.

Dialogue (3)

A : Nyuwun sewu Mas Bei, nyuwun pirsa. Beskap pesenanku wingi wis dadi?

Excuse me, Mas Bei, I would like to ask you a question. Is the jacket I ordered yesterday ready?

B : Durung dadi.

Not yet.

A : Sesuk bisa dadi apa ora? [Target sentence, polite] Yen ora dadi ora sah digarap! [Target sentence, polite] Minggu ngarep wae, merga aku arep nyang Jakarta.

Could it be ready or not tomorrow? If it is not ready, you shouldn't make it! Next week would be ok, because I'm going to Jakarta.

B : Mengko awan wis dadi, kok.

This afternoon this jacket will be ready. I'm sure.

Dialogue (4)

A : Ka. ${ }^{15}$ Beskap pesenanku wingi wis dadi?

$\mathrm{Ka}$. Is the jacket I ordered yesterday ready?

$15 \quad K a$ is a short name of the speaker $\mathrm{B}$. 
B : Nyuwun sewu Mas Bei, lali aku. Durung dadi. Lagi akeh pesenan. I'm really sorry, Mas Bei, I forgot it. It's not ready yet. I've got a lot of orders.

A : Lho, piye ta, kowe ki. Wingi kandhamu bisa dadi. Sesuk arep tak enggo. Mengko sore kudu dadi! [Target sentence, impolite]

Well, that's your fault. Yesterday, you said it could be finished. I'm going to wear it tomorrow. This afternoon should be ready.

B : Iya, iya. Nyuwun pangapunten Mas Bei. Mengko bengi takaturake neng dalem.

Well, well, I'd like to ask for the apology, Mas Bei. Tonight I'll deliver it to your home.

Dialogue (5)

A : Ka. Beskap pesenanku wingi wis dadi?

Ka. Is the jacket I ordered yesterday ready?

B : Nyuwun sewu Mas Bei, lali aku. Durung dadi. Lagi akeh pesenan.

I'm really sorry, Mas Bei, I forgot it. It's not ready yet. I've got a lot of orders.

A : Sesuk bisa dadi apa ora? [Target sentence, impolite] Yen ora dadi ora sah digarap! [Target sentence, impolite] Tak golek penjahit liyane.

Could it be ready or not tomorrow? If it is not ready, you shouldn't make it! I'll look for another tailor.

B : Iya, iya. Nyuwun pangapunten Mas. Mengko bengi takaturake neng dalem.

Well, well, I'd like to ask for the apology, Mas Bei. Tonight I'll deliver it to your home.

Dialogue (6)

A : Ka. Beskap pesenanku wingi wis dadi?

$\mathrm{Ka}$. Is the jacket I ordered yesterday ready?

B : Nyuwun sewu Mas Bei, lali aku. Durung dadi. Lagi akeh pesenan.

I'm really sorry, Mas Bei, I forgot it. It's not ready yet. I've got a lot of orders.

A : Tulung Dhik. Sesuk arep tak enggo.

Mengko sore kudu dadi! [Target sentence, polite] Aku perlu tenan, iki. Tulung, ya, bisa ta?

Please, understand me, my little brother. I'm going to wear it tomorrow. This afternoon should be ready. I badly need the jacket. Please help me, won't you?

B : Iya, bisa mas. Nyuwun pangapunten lho Mas. Mengko bengi takaturake neng dalem.

OK, my brother. I'll do my best. I'm really sorry, Brother. Tonight I'll deliver it to your home. 
The target sentences were: (i) Mengko sore kudu dadi 'this afternoon it should be ready' (ii) Yen ora dadi ora sah digarap 'If it is not ready, you shouldn't do it'; and (iii) Sesuk bisa dadi apa ora?! 'Could it be ready or not tomorrow?!' The dialogues were recorded from three male native speakers who took turns in taking the role of speaker A. From the 64 target utterances recorded I chose ten utterances ((4(i) + 2(ii) +4 (iii)) to be used for the prosodic research. ${ }^{16}$

Based on the acoustic analysis of these data close-copy stylizations were made. These were subsequently manipulated by modification of duration, pitch contour and fundamental frequency (F0). Figures 2 and 3 show the result of such manipulations: the utterances shown differ in duration and pitch contour. The utterance in Figure 2 is specified by its falling pitch contour (declination) as well as by its duration $(1.403 \mathrm{~ms})$. The utterance in Figure 3 is specified by its rising pitch contour as well as its short duration $(0.99 \mathrm{~ms})$.

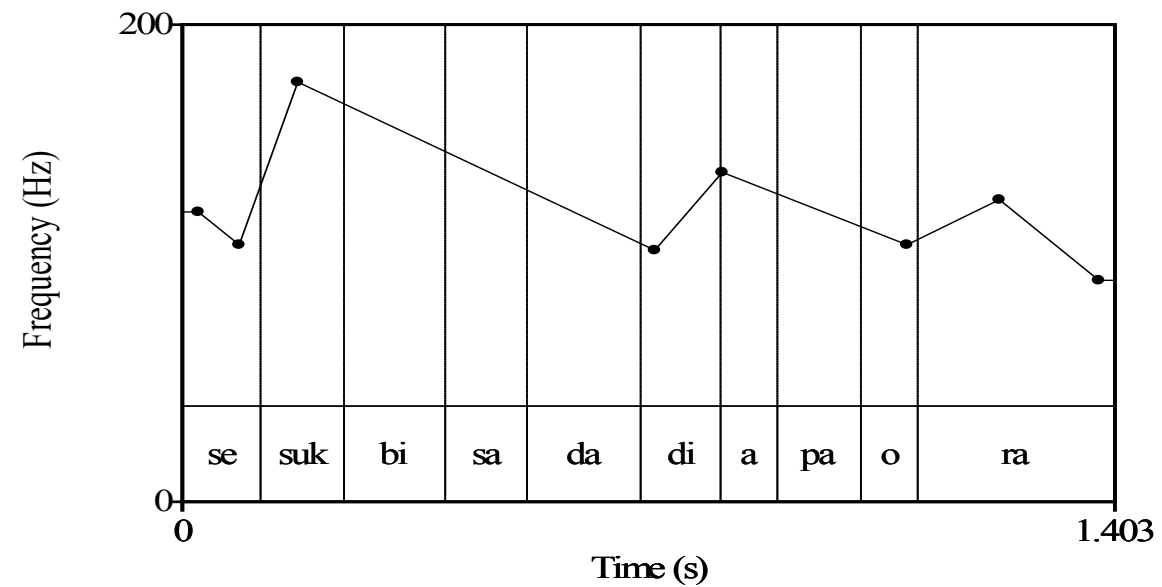

Figure 2. Lengthened duration and final declination.

Sesuk bisa dadi apa ora?

In this way, 90 stimuli were created for the perception tests: These 90 stimuli, to be discussed below, were presented to 24 subjects in order to be judged to what extent they were perceived as polite or impolite. The results were analysed statistically with ANOVAs (Analysis of variant). Based on these statistic analyses, the characteristic prosodies conveying politeness and impoliteness of utterances were discovered.

\subsection{PERCEPTION TEST}

In a perception test, a listener's judgment on recorded utterances is asked. In this research, perception tests were conducted in order to acquire judgments and the degree of politeness of the utterances presented to the listeners. Twenty-four subjects, all native speakers of Javanese - the employees of

16 Criteria for selection were: (i) acoustic analysis, (ii) the naturalness of the prosody produced, and (iii) auditory clarity of the recording. 


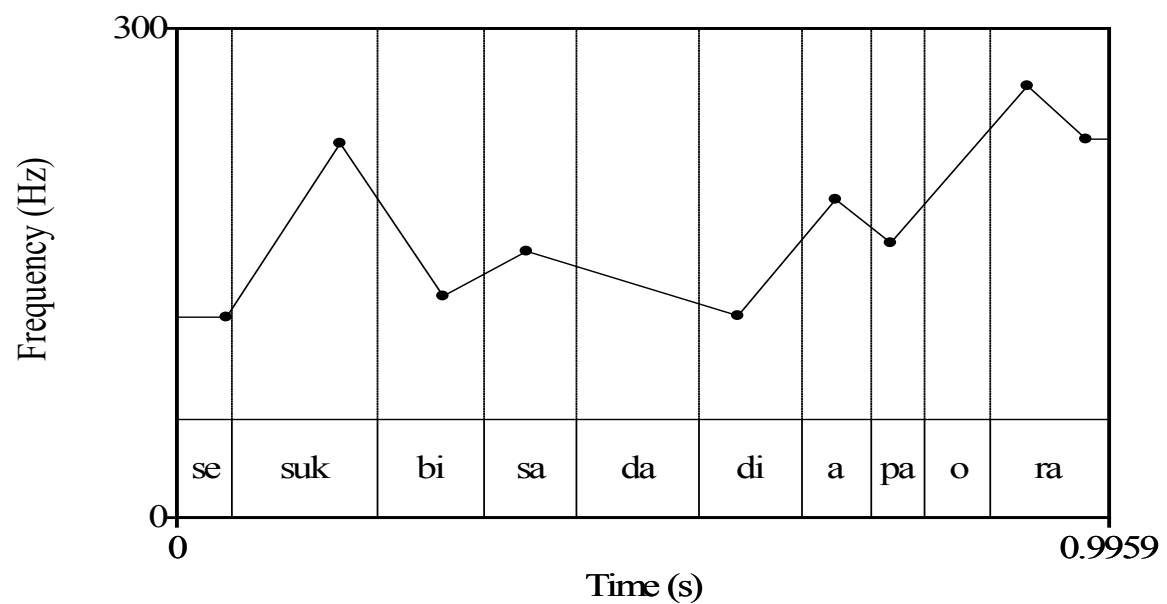

Figure 3. Shortened duration and final rising pitch contour. Sesuk bisa dadi apa ora?

Faculty of Humanities, University of Indonesia - were informed that they were going to hear a dialogue. They were asked to assume that they were the addressees of the first (and final) utterances in the dialogue. By means of this technique, the subjects were hoped to perceive and give a judgment of the degree of politeness of the target utterances addressed to them. The dialogues in question, consisted of a carrier dialogue, presented above, and the target sentences (i) Mengko sore kudu dadi 'This afternoon it should be ready', (ii) Yen ora dadi ora sah digarap! 'If it is not ready, you shouldn't do it!', (iii) Sesuk bisa dadi apa ora? 'Could it be ready tomorrow or not?', in which the underlined word groups are the focus of the information. These target sentences were embedded in the following dialogue:

(i) A : Beskap pesenanku wingi wis dadi?

Is the jacket I ordered yesterday ready?

B : Durung dadi.

Not yet.

A : Mengko sore kudu dadi!

This afternoon should be ready.

(ii) A : Beskap pesenanku wingi wis dadi?

Is the jacket I ordered yesterday ready?

B : Durung dadi.

Not yet.

A : Yen ora dadi ora sah digarap!

If it is not ready, you shouldn't make it!

(iii) A : Beskap pesenanku wingi wis dadi?

Is the jacket I ordered yesterday ready?

B : Durung dadi.

Not yet. 
A : Sesuk bisa dadi apa ora?

Could it be ready or not tomorrow?

Each dialogue was presented twice. The recorded utterances were played to the listeners in the language laboratory. They heard all of the utterances with good quality earphones individually.

The subjects were asked to judge the degree of politeness by choosing one of the following five politeness grades on the answer sheet:

grade 1: very impolite,

grade 2: impolite,

grade 3: rather polite,

grade 4: polite, or

grade 5: very polite.

\section{EXPERIMENT}

\subsection{EXPERIMENT 1: MODIFICATION OF DUR ATION}

The target utterances tested in this experiment were ten selected original utterances as well as the utterances, which were produced in the synthesis of the ten selected original utterances. As indicated above these were: (i) Mengko sore kudu dadi (4 utterances), (ii) Yen ora dadi ora sah digarap! (2 utterances), and (iii) Sesuk bisa dadi apa ora? (4 utterances). ${ }^{17}$ Of each target utterance, two syntheses were made with modified duration. This modification was only applied to the focus of the utterance in question.

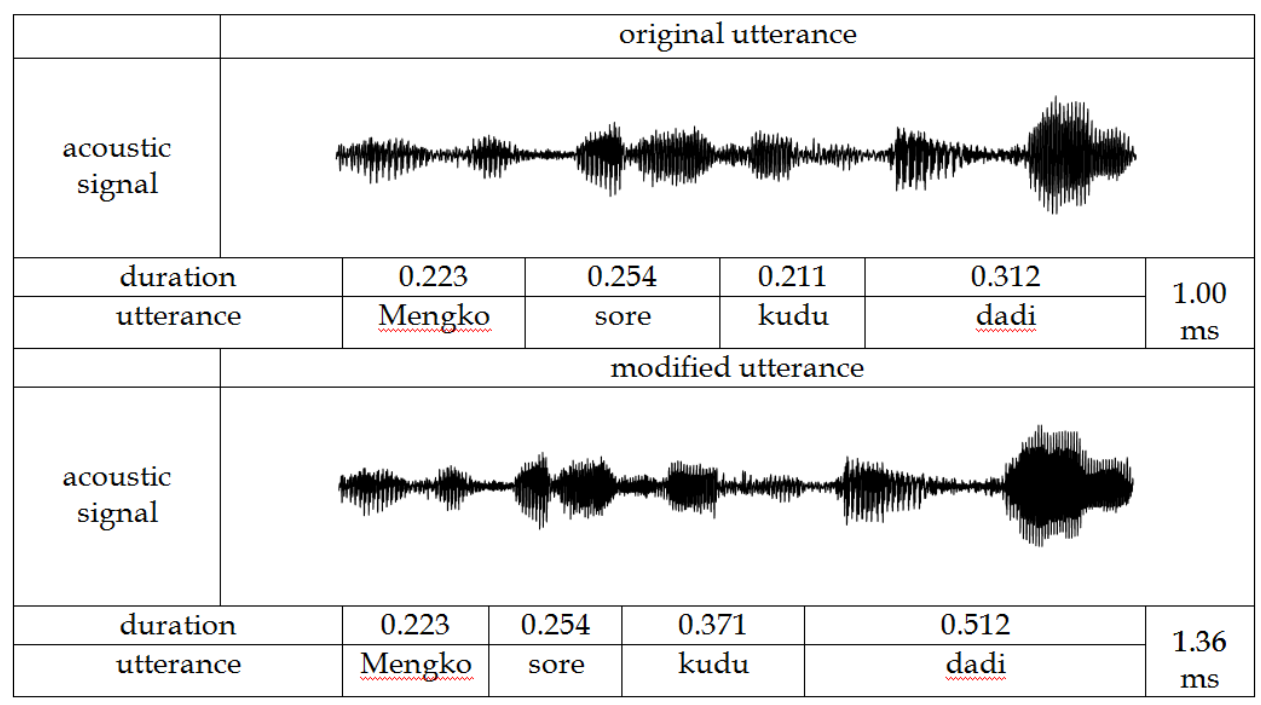

Figure 4. Acoustic modification of duration.

Mengko sore kudu dadi.

17 Stimuli code numbers (i): 1.1, 1.2, 1.3, 1.4; (ii): 2.1, 2.2; (iii): 3.1, 3.2, 3.3, 3.4. 
In order to maximize the contrast in the parameter involved, the duration modifications of the focused sections of the utterances were conducted in two ways. In the first modification, the duration on the target utterance was made $0.3 \mathrm{~ms}$ shorter than the original utterance. In the second modification, it was made $0.3 \mathrm{~ms}$ longer than the original one. Therefore, for each target utterance, three stimuli were presented, namely (1) the original utterance, (2) the utterance with shortened duration, and (3) the utterance with lengthened duration. The total number of stimuli tested in this experiment was consequently $30(3 \mathrm{x}$ $(4+2+4)$ utterances $)$.

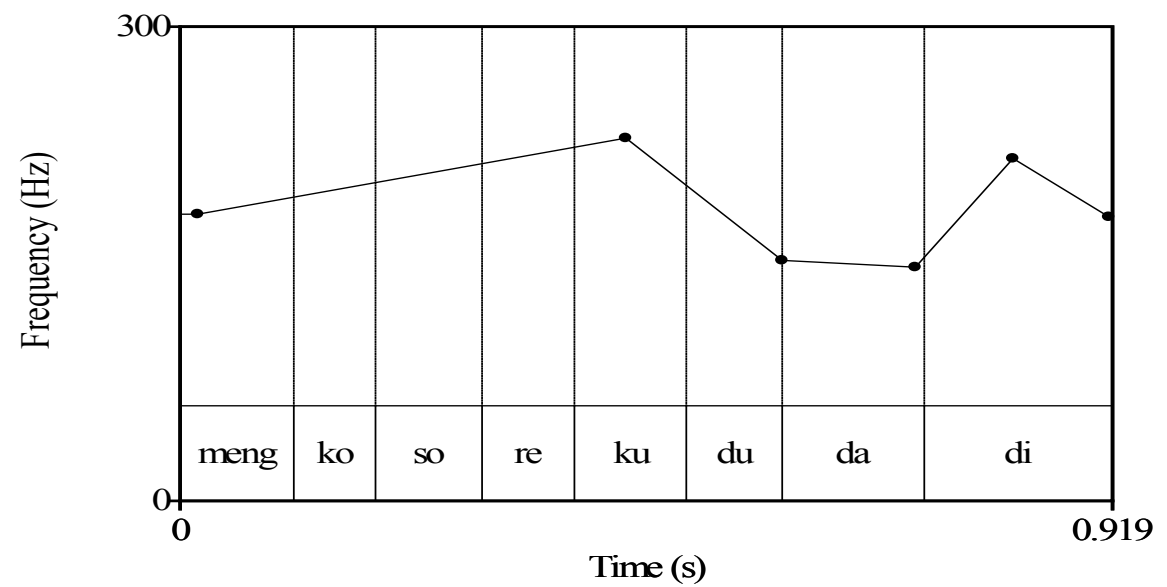

Figure 5a. The original of pitch contour.

Mengko sore kudu dadi.

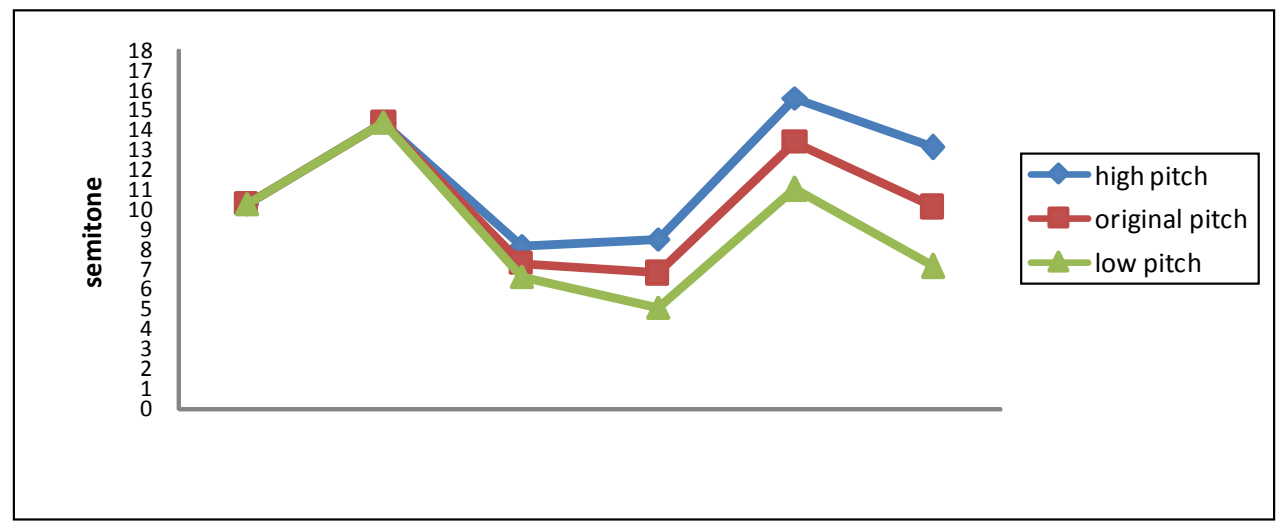

Figure $5 \mathrm{~b}$. Modification of pitch contour.

Mengko sore kudu dadi.

\subsection{EXPERIMENT 2: MODIFICATION OF PITCH CONTOUR}

Similar to the previous experiment, the target utterances tested in this experiment were the ten selected original utterances as well as the utterances 
synthesized by means of modification of the pitch contour baseline slope. Again, only the utterance focus was modified, similar to what was done in Experiment 1. Each of the original utterances produced two syntheses. In the first one, modification was made by increasing the pitch contour baseline slope, whereas the second one was made by decreasing it. As the following figure shows, this increase and decrease were gradual, reaching a maximal contrast between both manipulated contours of 6 semitones at the end of the utterance.

\subsection{EXPERIMENT 3: MODIFICATION OF FUNDAMENTAL FREQUENCY (FO)}

Similar to the Experiments 1 and 2, the target utterances tested in this experiment were the ten original utterances as well as the 20 synthesized utterances modified in their fundamental frequency throughout the entire utterance. The differences of the fundamental frequency between the original utterances with both modified utterances were 3 semitones. The listening experiment was similar to both earlier experiments.

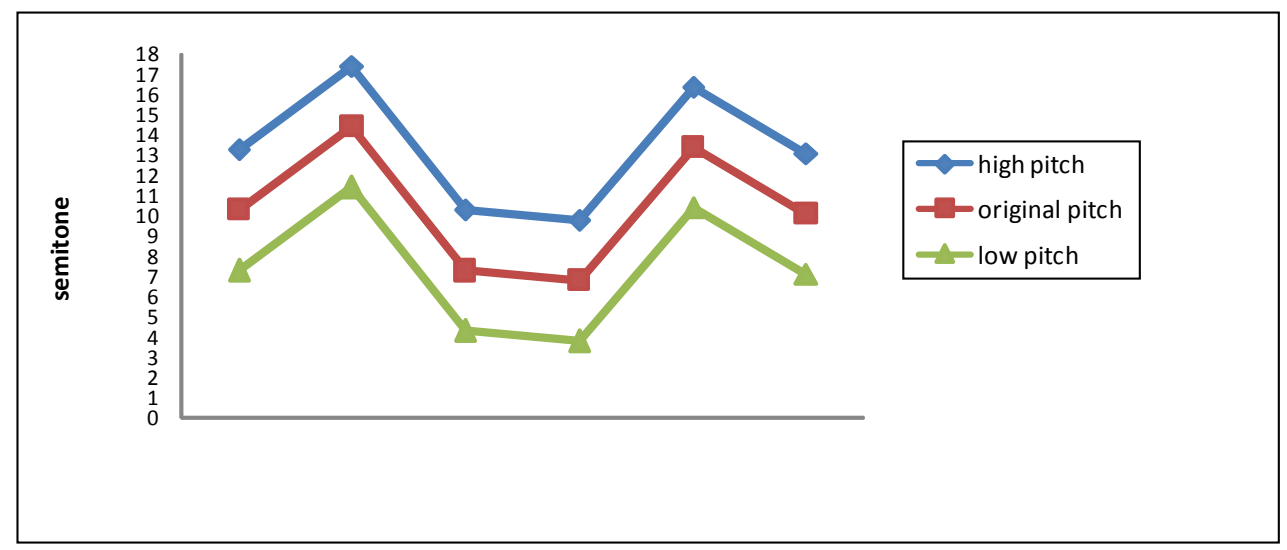

Figure 6. Modification of fundamental frequency.

Mengko sore kudu dadi.

\section{RESULT AND DISCUSSION}

\subsection{EXPERIMENT 1}

The total number of stimuli tested in this listening experiment were 30 utterances, consisting of three target utterances: (i) Mengko sore kudu dadi (12 utterances), (ii) Yen ora dadi ora sah digarap! (6 utterances), and (iii) Sesuk bisa dadi apa ora? (12 utterances). A one way analysis of variant (ANOVA, $a=.05$ ) shows that there was a significant difference in the percentage scores for the degree of politeness, that is $\mathrm{F}=34.420, \mathrm{p}<.001$. This statistic analysis shows that all stimuli were judged as having a different politeness grade. Figure 7 shows the politeness grade differences between the original utterances and the modified utterances. The first modified utterances were those with shortened duration of the focused final part of the utterance, whereas the 
second modified utterances were those with lengthened duration. The degree of politeness for each tested utterance in Figure 7 is the average of what the 24 subjects of the test indicated.

The stimuli of utterance (i), that is Mengko sore kudu dadi, consisted of four original utterances produced in the different politeness grades. The resultant scores in the perception test show that the first of the two original utterances, namely stimuli numbers 1.1 and 1.2 , were considered as rather polite utterances, whereas the second of the two utterances: stimuli numbers 1.3 and 1.4, as impolite utterances. The judgments concerning the original utterances show that all original utterances were valid data, representing "rather polite" and "impolite" utterances.

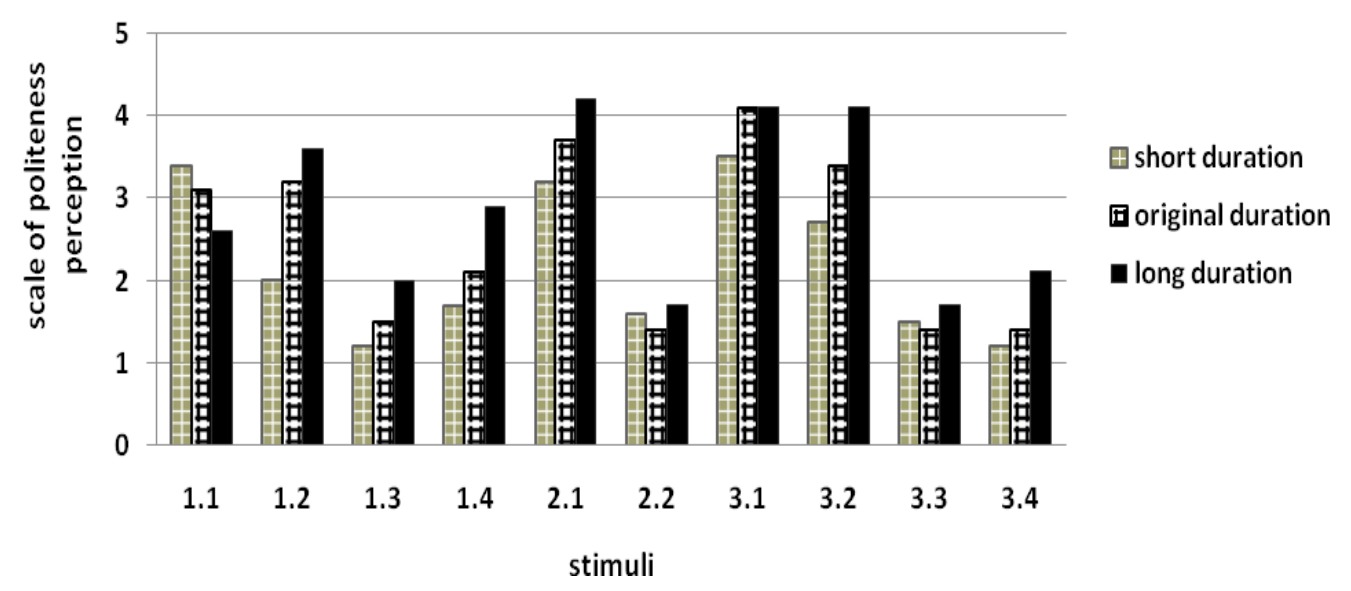

Figure 7. Perception changes in relation to modification of duration

The perception of the stimuli produced by the modification of the duration to each of the four original utterances shows differences with regard to the degree of politeness. Nevertheless, the differences of the politeness grade between the original and the modified utterances were not significant. A post hoc test bonferroni shows that the $0.3 \mathrm{~ms}$ differences in duration time are insufficient to produce statistically significant results $(p>.05)$. However, the differences of the subjects' judgments on the modified pairs of utterances which differed 0.6 $\mathrm{ms}$ in length were significant $(\mathrm{p}<.005)$. The longer duration was significantly perceived as more polite.

Figure 7 shows that politeness perception of utterance number 1.1 deviates from the general pattern, namely that the shortening of the duration results in a decrease of the degree of perceived politeness, whereas lengthening of the duration has the opposite effect. For the perception of utterance 1.2, it was the way around. This result indicates that extended duration does not always convey greater politeness. Apparently, it can also convey impoliteness.

Mark the utterance of B in the following Javanese dialogue.
A: Menapa panjenengan sampun rampung? Have you finished?
B: Sampun. Yes, I have. 
In natural dialogue, " $\mathrm{B}$ " utters the word Sampun to answer the question of " $\mathrm{A}$ " within a normal duration range. When " $\mathrm{A}$ " repeats the question to confirm " $B$ ' $s$ " answer, " $B$ " repeat his/her answer with longer duration. This could be interpreted, however, as face threatening, namely in the sense of "didn't you hear what I said, you blockhead". In other words, lengthened duration of sampun may call forth a perception of impoliteness.

The stimuli of utterance (ii), that is, Yen ora dadi ora sah digarap! Consisted of two original utterances produced in opposite politeness contexts. The first ${ }^{18}$ was produced in a situation in which politeness was required, the second ${ }^{19}$ in a situation in which the opposite was the case. As with the stimuli for utterance (i), the production and perception of the utterances corresponded. The first original utterance, produced as a polite utterance was also perceived as a polite utterance. The second original utterance, produced as an impolite one was also perceived as such. This parallelism between production and perception indicates that the two original utterances were valid as input data for the tests and the modifications.

The judgments of the stimuli, which were modified for duration were ambiguous. Changes in the politeness perception only appeared in stimulus 2.1 polite version. Nevertheless, the changes in the politeness perception of this directive command were relatively lower than was the case with the politeness perception of the directive statements. Lengthening of the duration with 0.25 $\mathrm{ms}$ in the original version of 2.1 raised the perceived degree of politeness perception, albeit only slightly: the level of politeness remained the same (grade 4). A post hoc test bonferroni shows that the difference of duration time of $0.6 \mathrm{~ms}$ between both modified utterances significantly corresponded with the difference in politeness perception $(\mathrm{p}<.001)$. There was no change in the perceived politeness grade with utterance (ii) impolite version. It was each time perceived as impolite, in spite of a duration difference extending to $0.6 \mathrm{~ms}$.

The stimuli of utterance (iii), that is, Sesuk bisa dadi apa ora? consisted of four original utterances produced in different politeness situations. The first one was a polite utterance. The second one was "rather polite", the third and fourth ones impolite. The perception tests of 12 stimuli show that not all of the changes in duration in the directive questions changed the politeness perception. A post hoc test bonferroni shows that the differences in the politeness perception were significant $(p<.001)$ for the stimuli 3.2 (second polite version) and 3.4 (second impolite version).

Lengthening of the duration with $0.2-0.3 \mathrm{~ms}$ in the original versions of these stimuli changed the politeness perception significantly $(p<.05)$. The differences in duration time of $0.5-0.6 \mathrm{~ms}$ between the modified utterances were also accompanied by a significant change in the politeness perception ( $p$ $<$.001). The scores of the perception test for these utterances show that longer duration time corresponds with a higher politeness grade, whereas shorter

18 Stimulus code numbers: 2.1 .

19 Stimulus code numbers: 2.2 . 
duration corresponds to a lower politeness grade.

The changes in the politeness perception of the original versions of 3.1 and 3.3 (respectively polite and impolite) as compared to their modifications appeared to be not significant. Lengthening as well as shortening of the duration of the original 3.1 with $0.3 \mathrm{~ms}$ did not change the politeness perception significantly $(p=1.000$ and $p=0.149)$. Modification in either direction of the duration of the original utterance $3.3 \mathrm{did}$ not change the perceived impolite grade at all $(\mathrm{p}=1.000)$.

\subsection{EXPERIMENT 2}

Similar to Experiment 1, the total number of stimuli in experiment 2 was 30 utterances, consisting again of the three target utterances: (i) Mengko sore kudu dadi ( $3 \times 4$ utterances), (ii) Yen ora dadi ora sah digarap! (3x2 utterances), dan (iii) Sesuk bisa dadi apa ora? ( $3 \times 4$ utterances). The result of the perception test of the original utterances in this experiment was the same as the result in experiment 1 . A one way analysis of variant (ANOVA, $\alpha=.05$ ) shows that there was a significant difference in the percentage scores for the politeness grade, that is, $\mathrm{F}=41.293, \mathrm{p}<.001$. This statistic analysis shows that all stimuli corresponded to different perceptions of politeness (see Figure 8).

A post hoc test bonferroni showed that the majority of the differences between the original utterances and their modifications for contour were not significant. In all cases the degree of politeness did not shift to a neighboring level. In other words, the original utterance and its modifications were perceived as having the same politeness grade. The different perception scores for both contour modifications of the original utterances 3.1, 3.2, and 3.4 were significant, however $(\mathrm{p}<.005)$.

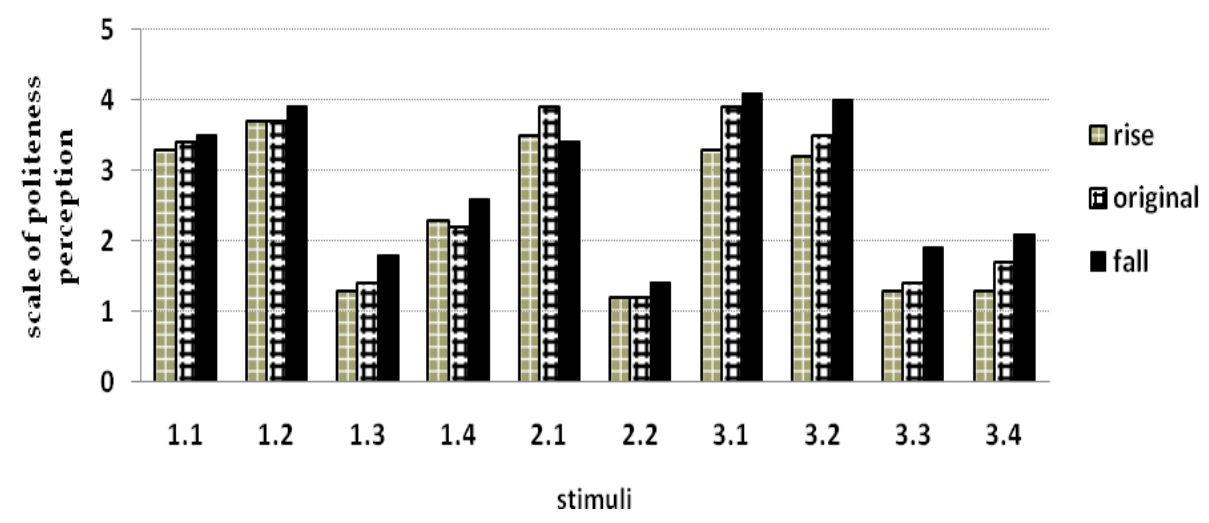

Figure 8. Perception changes in relation to modification of contour

Based on the results of a post hoc test bonferroni, we may conclude that modifications of baseline slope (in this experiment) did not change politeness perception significantly, except with the directive question utterances. Figure 8 shows that changes in the politeness perception consistently corresponded to 
changes in the baseline slope of the directive questions, that is with the stimuli 3.1-4. However, the politeness perception with stimulus 3.3 does not change significantly $(p>.05)$. The result of the perception test for the stimuli 3.1-4 shows that a rising baseline slope tends to make an utterance more impolite; conversely, a falling baseline slope tends to make an utterance more polite.

\subsection{EXPERIMENT 3}

As with Experiments 1 and 2, the total number of stimuli in experiment 3 was 30 utterances, consisting of the three target utterances: (i) Mengko sore kudu dadi (3x4 utterances), (ii) Yen ora dadi ora sah digarap! (3x2 utterances), dan (iii) Sesuk bisa dadi apa ora? ( $3 \times 4$ utterances). A one way analysis of variant (ANOVA, a $=.05$ ) shows that there was a significant difference in the percentage scores for politeness grade, that is, $F=42.300, p<.001$. This statistic analysis shows that all stimuli correspond to different politeness grades. Figure 9 shows the differences in politeness perception between the original utterance and the two utterances modified by lowering and raising of the fundamental frequency $(\mathrm{F} 0)$.

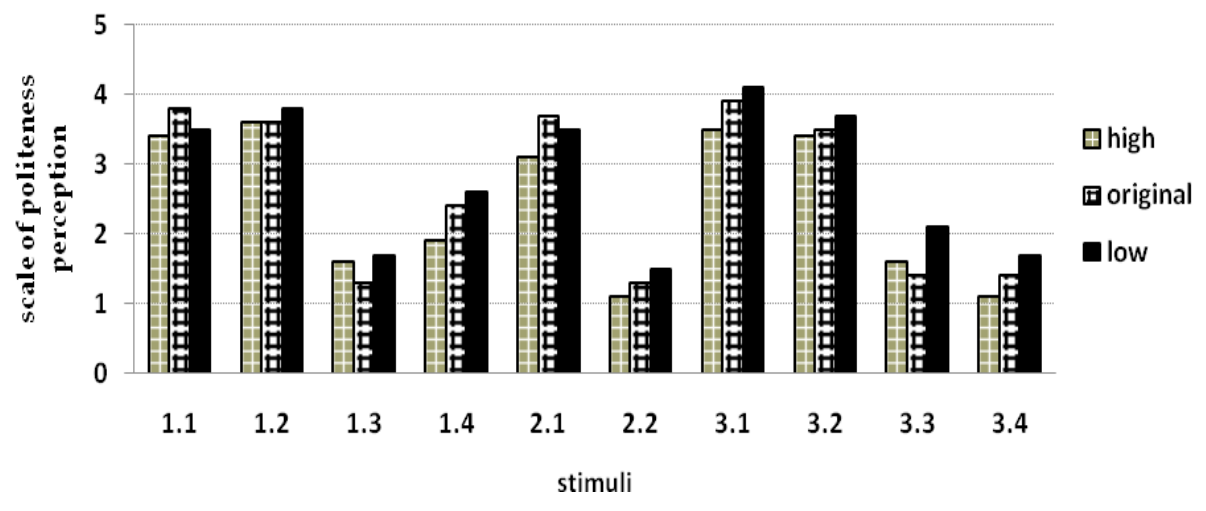

Figure 9. Perception changes in relation to modification of Fo

The results of the perception experiment 3 were similar to those of the previous experiment. A post hoc test bonferroni shows that the majority of the politeness judgments of the original and the modified utterances were not significantly different $(p>.05)$. The original and the modified stimuli were still perceived as having the same politeness grade. In addition, the changes in the politeness scores were not consistent. In other words, the stimuli of this experiment were difficult to be perceived as utterances, which convey different degrees of politeness. The judgements were only significantly consistent $(p<.05)$ for stimulus 3.4.

The different perception scores for each pair of modifications of the three original directive questions 3.1, 3.3 and 3.4 indicate a significant shift $(\mathrm{p}<$ .005) from one politeness grade to the next. A decrease of the fundamental frequency increased the politeness perception, that is from very impolite (grade 1) to impolite (grade 2). Conversely, an increase of the fundamental 
frequency resulted in a decrease of the perceived politeness from impolite to very impolite (grade 1). The politeness perception scores for the stimuli 3.3 were inconsistent. Increase of the fundamental frequency did not change the degree of politeness.

The overall tendency shown by experiment 3 is that the higher the fundamental frequency of the utterance, the lower the perceived politeness grade. Conversely, the lower the fundamental frequency, the higher the perceived politeness grade of the utterance.

\section{CONCLUSION}

In face-to-face conversation, speech politeness can be immediately perceived by the addressee. Even though the chosen words do not violate the politeness principle as described above, the selected prosody may reveal impoliteness. The speaker chooses the prosody, which in most cases corresponds with the speech situation and in all cases to the intention he/she wants to communicate. When the speaker wants to reveal his/her power or wants the hearer to "lose face", he/she uses the appropriate prosody.

This research made use of the politeness principles described above. The target utterances, which were the basis for the perception tests were created to convey the politeness or impoliteness included in the carrier dialogue. In passing their judgments, the 24 subjects who participated in the tests were asked to react as if they were the addressee of the target utterance in the dialogue. They had to judge to what extent the prosodic characteristics of the utterances in question created the impression that the speaker meant to be polite or impolite.

As the results of the listening experiments show, prosodic oppositions do not always correspond significantly with different politeness scores. Experiment 1, in which the effects of duration differences were investigated, shows that there is a significant correspondence between duration and perceived degree of politeness. In Experiment 2, in which the baseline slope was modified, the only significant differences were those in the scores for directive question stimuli. In Experiment 3, which tested the effects of the modification of the fundamental frequency, most of the score differences appeared to be not significant. Moreover, the correspondences between the height of the fundamental frequency and the perceived politeness differed between stimuli. In all instances, the perceived degree of politeness remained the same for the original utterances and for their modifications.

The general conclusion can be that this pilot research suggests that prosodic politeness in Javanese is realized by means of rhythm, in this case duration, as well as by the pitch movement characteristics of the intonation contour. The height of the fundamental frequency throughout the utterance has no effect on the politeness perception. In my opinion, the relative height of the fundamental frequency (with the same male or female speaker) is related to emphasis rather than to politeness.

The three experiments in this research are evidently insufficient to 
discover all possible relevant characteristics of the politeness prosodies. The experiment of duration modification needs to be complemented with tests for duration modification in the syllables, especially the stressed syllables. Further modifications of the pitch movements, as well as of pitch range need to be tested. This research did not take voice intensity into account as a possible parameter. In the listening tests, the subjects experienced difficulties differentiating politeness grades when they heard the stimuli continuously. Consequently, the listening tests should be designed in such a way as to enable the subjects to judge accurately. Each time, the minimal pairs of polite and impolite utterances should be presented together in the tests.

\section{REFERENCES}

Austin, J.L. 1984. How to do things with words. Oxford/New York: Oxford University Press.

Brown, P. and S.C. Levinson. 1987. Politeness; Some universals in language usage. Revised version. Cambridge: Cambridge University Press. [First edition 1978.]

Cruttenden, Alan. 1997. Intonation. Second Edition. Cambridge: Cambridge University Press. [First edition 1986.]

Errington, J. Joseph. 1985. Language and social change in Java; Linguistic reflexes of modernization in a traditional royal polity. Ohio: Ohio University.

Errington, J. Joseph. 1988. Structure and style in Javanese; A semiotic view of linguistic etiquette. Philadelphia: University of Pennsylvania Press.

Grice, H.P. 1991. "Logic and Conversation”, in: Steven Davis (ed.), Pragmatics; A reader, pp. 305-315. Oxford: Oxford University Press.

Gunarwan, Asim. 2007. Pragmatik; Teori dan kajian Nusantara. Jakarta: Penerbit Universitas Atma Jaya.

't Hart, J., R. Collier, and A. Cohen. 1990. A perceptual study of intonation; An experimental-phonetic approach to speech melody. Cambridge: Cambridge University Press.

Heuven, Vincent J. van. 1994. "Introducing prosodic phonetics", in: Cecilia Odé and Vincent J. van Heuven (eds), Experimental studies of Indonesian prosody, pp. 1-26. Leiden: Vakgroep Talen en Culturen van Zuidoost-Azië en Oceanië, Rijkuniversiteit te Leiden.

Heuven, Vincent J. van, and Ellen van Zanten. 2007. Prosody in Indonesian languages. Utrecht: Landelijke Onderzoekschool Taalwetenschap (LOT).

Leech, G.N. 1983. Principles of pragmatics. London: Longman.

Nooteboom, Sieb. 1999. "The prosody of speech; Melody and rhythm", in: William J. Hardcastle and John Laver (eds), The handbook of phonetics sciences, pp. 640-673. Oxford: Blackwell.

Poedjosoedarmo, Soepomo, 1979. Tingkat tutur bahasa Jawa. Jakarta: Pusat Pembinaan dan Pengembangan Bahasa, Departemen Pendidikan dan Kebudayaan.

Rahyono, F.X. 2002 “Representamen kebudayaan Jawa; Teknik komparatif referensial pada teks Wedhatama", Wacana, Jurnal Ilmu Pengetahuan Budaya 
4/1 (April): 14-33.

Rahyono, F.X. 2003. “Intonasi ragam bahasa Jawa Keraton Yogyakarta; Kontras deklarativitas, interogativitas, dan imperativitas". Disertasi, Universitas Indonesia, Depok.

Rahyono, F.X. 2005. "Kearifan dalam bahasa; Sebuah tinjauan pragmatis terhadap profil kebahasaan media massa pada Masa Pascaorde Baru", Jurnal Makara; Seri Sosial Humaniora 9/2 (Desember): 46-56.

Searle, John R. 1991. "Indirect speech acts", in: Steven Davis (ed.), Pragmatics; A reader pp. 265-277. Oxford: Oxford University Press.

Thomas, Jenny. 1996. Meaning in interaction; An introduction to pragmatics. London: Longman.

Yule, G. 1996. Pragmatics. Oxford: Oxford University Press. 